\title{
Evaluation of the lard oxidative stability added with rosemary extract and rosemary essential oil
}

\section{Avaliação da estabilidade oxidativa da banha adicionada de extrato de alecrim e óleo essencial de alecrim}

\author{
Luís Guilherme Escobar de Carvalho; Selma Sanches Dovichi²; Ana Carolina da Silva ${ }^{3}$ \\ ${ }^{1}$ Aluno do Curso de Engenharia de Alimentos, Universidade Federal do Triângulo Mineiro, Uberaba, Minas Gerais, \\ Brasil. E-mail: Igescarvalho@gmail.com \\ ${ }^{2}$ Professora do Curso de Nutrição, Universidade Federal do Triângulo Mineiro, Uberaba, Minas Gerais, Brasil. E-mail: \\ selmasd@hotmail.com \\ ${ }^{3}$ Professora do Curso de Engenharia de Alimentos, Universidade Federal do Triângulo Mineiro, Uberaba, Minas Gerais, \\ Brasil. Orcid: 000-001-6272-6147. E-mail: ac.dasilva@yahoo.com.br
}

\begin{abstract}
The production of undesirable compounds from oxidative processes in oils and fats is a problem when it comes to extending shelf life or deep-fat frying foods. In this work the use of rosemary extract and rosemary essential oil in the lard submitted to thermoxidation was evaluated and compared with the synthetic antioxidant TBHQ. The extract obtained from solvent extraction and the rosemary essential oil were submitted to free radical analysis $\mathrm{DPPH}^{\circ}$ and $\mathrm{ABTS}^{\circ+}$, total phenolic compounds and total flavonoids. The lard was divided into four treatments: lard (control), lard $+100 \mathrm{mg} \mathrm{kg}^{-1} \mathrm{TBHQ}(\mathrm{L}+\mathrm{TBHQ})$, lard $+100 \mathrm{mg} \mathrm{kg}^{-1}$ rosemary extract $(\mathrm{L}+\mathrm{RE})$ and lard +100 $\mathrm{mg} \mathrm{kg}^{-1}$ rosemary essential oil $(\mathrm{L}+\mathrm{REO})$. The treatments were submitted to thermoxidation at $180^{\circ} \mathrm{C}$, where samples were taken off at intervals of $0,5,10,15$ and 20 hours. The samples were analyzed for free fatty acid content, peroxide index and conjugated dienes. The extract showed better antioxidant potential when compared to the essential oil $\left(15.20\right.$ and $18.51 \mathrm{mg} \mathrm{mL}^{-1}$ for EC 50 ; 917.87 and $321.71 \mu \mathrm{mol} E T \mathrm{~mL}^{-1}$, respectively). The analysis for total phenolics compounds and total flavonoids showed no statistical difference (99.55 and $80.88 \mathrm{mg} \mathrm{EAG} \mathrm{L}^{-1} ; 29.79$ and $31.42 \mu \mathrm{g}$ $\mathrm{ER} \mathrm{mL}^{-1}$, respectively). During the analysis of the thermoxidated lard, the rosemary essential oil showed results as favorable as those obtained by the antioxidant TBHQ, showing that the antioxidants from natural source can be a good alternative to synthetics ones.
\end{abstract}

Keywords: Lard; Natural antioxidant; Rosemary extract; Rosemary essential oil; Oxidation.

RESUMO: A produção de compostos indesejáveis provenientes de processos oxidativos nos óleos e gorduras é um problema quando se trata de prolongar a vida útil ou realizar a fritura de alimentos. Neste trabalho foi avaliado o uso do extrato do alecrim e do óleo essencial de alecrim na banha submetida a termoxidação e comparado com o antioxidante sintético TBHQ. O extrato obtido a partir da extração por solvente e o óleo essencial de alecrim foram submetidos às análises de radicais livres $D P P H^{\circ}$ e $A B T S^{\circ+}$, teor de compostos fenólicos totais e teor de flavonoides totais. A banha foi dividia em 4 tratamentos: banha (controle), banha $+100 \mathrm{mg} \mathrm{kg}^{-1}$ $T B H Q$, banha $+100 \mathrm{mg} \mathrm{kg}^{-1}$ extrato de alecrim, banha $+100 \mathrm{mg} \mathrm{kg}^{-1}$ óleo essencial de alecrim. Os tratamentos foram submetidos à termoxidação a $180^{\circ} \mathrm{C}$ e retiradas em intervalos de $0,5,10,15 \mathrm{e}$ 20 horas. As amostras foram submetidas às análises de ácidos graxos livres, índice de peróxidos e dienos conjugados. O extrato apresentou melhor potencial antioxidante perante o óleo essencial (15,20 e 18,51 mg mL ${ }^{-1}$ para $C E_{50} ; 917,87$ e 321,71 $\mu \mathrm{mol} E T \mathrm{~mL}^{-1}$, respectivamente). As análises para compostos fenólicos totais e flavonoides totais não demonstraram diferença estatística (99,55 e 80,88 mg EAG $\mathrm{L}^{-1} ; 29,79$ e 31,42 $\mu \mathrm{g} E R \mathrm{~mL}^{-1}$, respectivamente). Durante as análises das gorduras termoxidadas, o óleo essencial de alecrim demonstrou resultados tão favoráveis quanto os obtidos pelo antioxidante TBHQ, demonstrando assim que os antioxidantes de fontes naturais podem ser uma boa alternativa aos antioxidantes sintéticos.

Palavras-chave: Banha; Antioxidante natural; Extrato de alecrim; Óleo essencial de alecrim; Oxidação. 
INTRODUCTION

In the early 1950s, with the introduction of vegetable fat in Brazil and the campaigns aimed at changing habits in relation to animal fat consumption, the population began to replace lard, which until then was the only fat used for cooking, by vegetable fat (RESENDE, 2014).

Currently it is observed that with new researches and the globalization, the consumer profile has changed, appearing more conscious consumption forms in relation to industrial products. Thus, the lard was again comprehensively commercialized due to the search for the old habits and a more natural food. According to Oil World Annual (2018), world production of lard had a large increase, from 7.96 to 8.78 million tons from 2010 to 2017 , exceeding the production of butter (7.19 to 8.23 million tons) and vegetable oils such as corn oil ( 2.41 to 4.17 million tons) and olive oil (3.3 to 2.8 million tons) for the same period.

In order to decelerate the main chemical process responsible for the degradation of oils and fats, antioxidants are used by the industry to increase the shelf life of oils, fats and fatty foods. The antioxidants most commonly used are synthetic ones. Recent studies have shown that the degradation products of these antioxidants may have negative effects on human health such as carcinogenic effects and gastrointestinal hyperplasia in animal experiments, in humans these effects have not been established (BOTTERWECK et al., 1999; VENKATESH; SOOD; SHIVKUMAR, 2011).

The use of these antioxidants has been limited and many times prohibited in places such as Japan and the European Union, whereas in the USA the use of TBHQ cannot be combined with propyl gallate (PG) (VENKATESH; SOOD; SHIVKUMAR, 2011).

Considering the indications of problems that the consumption of these additives can be cause, many researches are being developed to discover the antioxidant capacity that exists in natural products, thus making substitution that brings benefits to the producer and the consumer.

Among the natural antioxidants most commonly used are tocopherols, phenolic acids and plant extracts. Many studies indicate that rosemary extract has high efficacy against fat lipid oxidation, in some cases even better than synthetic antioxidants such as butyl hydroxyl toluene (BHT) and butyl hydroxyl anisol (BHA) (WU et al., 1982; FANG; WADA, 1993; GORDON; KOURIMSKÁ, 1995; ALMEIDA-DORIA; REGITANO-D'ARCE, 2000; CASAROTTI; JORGE, 2014).

The goal of this present work was to evaluate the oxidative stability of the lard added to rosemary extract and rosemary essential oil as natural antioxidants.

\section{MATERIAL AND METHODS}

The rosemary was bought in the local herb market of Uberaba, state of Minas Gerais; its leaves were manually separated, washed with active chlorine (100 ppm) and dried in air oven at $50^{\circ} \mathrm{C}$ for 24 hours (up to constant weight). The extract was obtained using a solvent extraction method. The leaves were crushed, submerged in a mixture of acetone/ethyl alcohol/acetic acid in a ratio of 70:29.5:0.5 v/v/v with a ratio of $1: 10$ for dehydrated leaves and solvent (ALADEDUNYE; MATTHÄUS, 2014). The mixture was triturated in a homogenizer equipment, model N-150-01 by New Lab, and vacuum filtrated with a paper filter of grade 2 , this procedure was repeated twice, and the supernatants 
were combined. The residual solvent was evaporated at $60^{\circ} \mathrm{C}$ with a rotary evaporator. The lard, (Ebénezer trademark) classified as common lard, and the essential oil (branded Paladar) extracted by hydroextraction, were bought also in the local market. All analysis performed on rosemary extract and essential oil of rosemary were done in triplicate and all spectrophotometric analysis were performed using the spectrophotometer model SP-22 by Biospectro.

\section{Antioxidant activity of the rosemary extract and rosemary essential oil}

The antioxidant activity of rosemary extract and rosemary essential oil were determined using the 1,1-diphenyl-2-picrylhydrazyl free radical (DPPH') capture method described by Brand-Williams, Cuvelier and Berset (1995) and the 2,2'-azino-bis(3-ethylbenzthiazoline-6sulphonic acid) $\left(\right.$ ABTS $^{\circ+}$ ) free radical capture method described by $\mathrm{Re}$ et al. (1999) and modified by Kuskoski et al (2005). For the first method, solutions containing different concentrations of the extract and essential oil diluted in ethanol $\left(2 ; 4 ; 6\right.$ and $8 \mathrm{mg} \mathrm{mL}^{-1}$ ) were prepared. Aliquots of $0.3 \mathrm{~mL}$ of these solutions were added in $2.7 \mathrm{~mL}^{\circ}$ of DPPH solution, with a concentration of $40 \mu \mathrm{g} \mathrm{mL}^{-1}$ in methanol. The mixture was vigorously shaken in vortex and maintained for 30 minutes at room temperature in the dark. Then the absorbance was measured at $517 \mathrm{~nm}$, and values converted to antioxidant activity (maximum AA) by Equation 1. The control was prepared from $2.7 \mathrm{~mL}$ of $\mathrm{DPPH}^{\circ}$ solution without the presence of antioxidants and the blank from the pure solution of methanol.

$$
A A(\%)=\frac{\text { Abs control-Abs sample }}{\text { Abs control }} \times 100
$$

Where Abs controls and Abs sample stands for absorbance of the control and the sample, respectively, and AA (\%) stands for the antioxidant activity. A graph was constructed, as exemplified in Figure 1, from the antioxidant activity of each concentration. Using the linear regression equation obtained, the concentration required to reduce the initial concentration of DPPH by $50 \%\left(\mathrm{CE}_{50}\right)$ was the value for $x$ when the $y$ was replaced with $50 \%$. The line Equation for the graph is shown in the Equation 2 and the $\mathrm{R}^{2}$ for the linear regression in this equation is 0.9988 .

$$
y=2.8203 x-1.8595
$$

Using the $\mathrm{EC}_{50}$ in the Equation 3, the AAI (Antioxidant Activity Index) suggested by Scherer and Godoy (2009) was found, and according to Table 1 was possible to classify the antioxidant potential.

$$
A A I=\frac{[D P P H \cdot] \text { final }}{E C 50}
$$


Figure 1 . Antioxidant Activity for Rosemary Essential Oil for the DPPH method

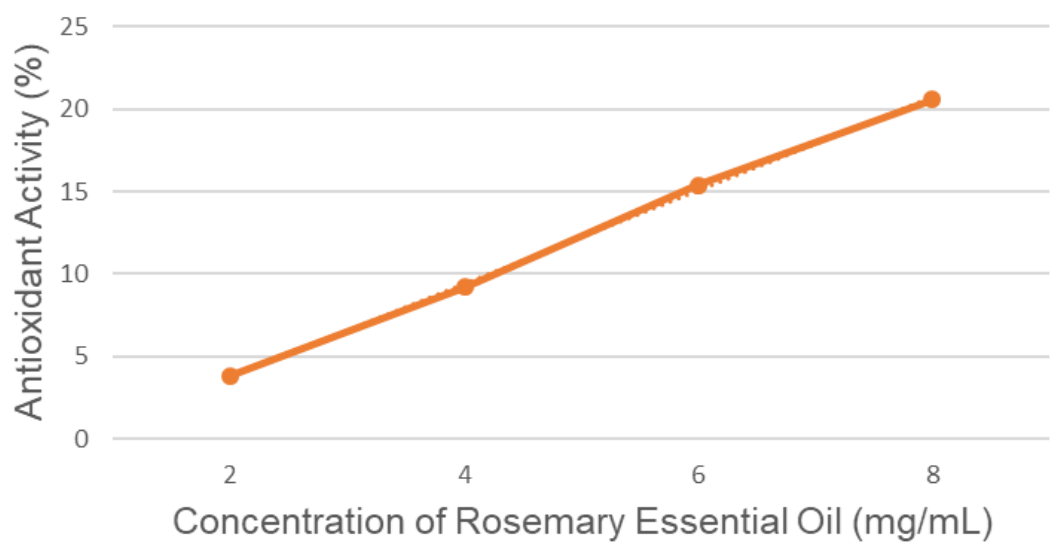

Table 1. Activity potential according to Antioxidant Activity Index

\begin{tabular}{ll}
\hline AAl & Antioxidant capacity \\
\hline$<0.5$ & Week \\
0.5 to 1.0 & Moderate \\
1.0 to 2.0 & Strong \\
$>2.0$ & Very strong \\
\hline Source: Scherer and Godoy (2009) &
\end{tabular}

For the second method, a standard curve was constructed reading $30 \mu \mathrm{L}$ of different concentrations of Trolox, from 100 to $2000 \mu \mathrm{M}$, with ethyl alcohol and $3.0 \mathrm{~mL}$ of $\mathrm{ABTS}^{\circ+}$ radical. Readings $(734 \mathrm{~nm})$ were taken after 6 minutes of reaction in the dark. The Equation 4 represents the linear regression equation found for the standard curve; the $R^{2}$ for the line regression is 0.9966 .

$$
y=-0.0003 x+0.7216
$$

Afterwards, $30 \mu \mathrm{L}$ of samples of rosemary extract and rosemary essential oil at a concentration of $10 \mathrm{mg} / \mathrm{ml}$ were added in test tubes containing the ABTS radical. Soon after, the readings $(734 \mathrm{~nm})$ were taken using ethyl alcohol as blank and the absorbance founded was replaced at the Equation 4 . The results were expressed in $\mu$ mol equivalent of trolox $\mathrm{mL}^{-1}$ of sample ( $\mu \mathrm{mol} \mathrm{ET} \mathrm{mL}^{-1}$ sample).

\section{Total phenolics compounds and total flavonoids}

The total phenolics compounds were determined by the method of Folin-Ciocalteau described by Singleton and Rossi (1965). A standard curve was constructed using $250 \mu \mathrm{L}$ of different concentrations of gallic acid, from 0 to $150 \mathrm{mg} \mathrm{mL}^{-1}$, added with $250 \mu \mathrm{L}$ of Folin-Ciocalteau reagent, $500 \mu \mathrm{L}$ of sodium carbonate $(20 \% \mathrm{w} / \mathrm{v})$ and $4 \mathrm{~mL}$ of distilled water. This mixture remained at rest for 2 hours at room temperature. The absorbance was measured at the wavelength of $765 \mathrm{~nm}$. Afterwards the gallic acid was replaced by the rosemary extract and rosemary essential oil $\left(10 \mathrm{mg} \mathrm{ml}^{-1}\right)$, the absorbance measured, and the value replaced at the line regression equation shown by the Equation 5 ; the $\mathrm{R}^{2}$ for 
the line regression is 0.9567 . Total phenolic compounds were expressed in $\mathrm{mg}$ of gallic acid equivalents $\mathrm{mL}^{-1}$ of sample (mg EAG L ${ }^{-1}$ sample).

$$
y=0.00684 x-0.00558
$$

The determination of the total flavonoid content was performed using the method proposed by Sobrinho et al. (2008). A standard curve was constructed through different concentrations of rutin, from 5 to $35 \mu \mathrm{g} \mathrm{mL}^{-1}$ with methanol, $0.6 \mathrm{~mL}$ of glacial acetic acid, $10.0 \mathrm{~mL}$ of metanolic pyridine $(20 \% \mathrm{w} / \mathrm{v})$ and $2.5 \mathrm{~mL}$ of aluminum chloride $\left(50.0 \mathrm{mg} \mathrm{mL}^{-1}\right)$. The measurement was at the wavelength of $420 \mathrm{~nm}$. Using a concentration of $10 \mathrm{mg} \mathrm{mL}^{-1}$ of the samples, rosemary extract and rosemary essential oil, added with the same reagents as in the standard curve. The reading was carried out at $420 \mathrm{~nm}$ and its values replaced on the regression line equation, represented by the Equation 6 , with $R^{2}$ of 0.9641 . Results were expressed as $\mu \mathrm{g}$ equivalent of rutin $\mathrm{mL}^{-1}$ of sample ( $\mu \mathrm{g} \mathrm{ER} \mathrm{mL}{ }^{-1}$ sample).

$$
y=0.061 x+0.0786
$$

\section{Treatments, samplings and analysis}

The treatments were prepared from the mixture of lard $(L)$ with rosemary extract $(L$ $+\mathrm{RE})$ and rosemary essential oil $(\mathrm{L}+\mathrm{REO})$ at a concentration of $100 \mathrm{mg} \mathrm{kg}^{-1}$. For the purpose of comparison, tests with the antioxidant TBHQ with the same concentration of $100 \mathrm{mg} \mathrm{kg}^{-1}$ in lard ( $\mathrm{L}+\mathrm{TBHQ}$ ) and the control without the presence of antioxidants $(\mathrm{L})$ were also carried out. The thermoxidation was conducted on a hot plate in $100 \mathrm{~mL}$ beakers. Addition of treatments $(60 \mathrm{~mL})$ in the beakers resulted in a surface to volume ratio of $0.4 \mathrm{~cm}^{-1}$. The samples were heated at $180^{\circ} \mathrm{C} \pm 5^{\circ} \mathrm{C}$. The thermoxidation was carried out using a discontinuous approach involving $10 \mathrm{~h}$ of heating per day. Samples were taken at time intervals of $0,5,10,15$ and 20 hours and stored at $-18^{\circ} \mathrm{C}$ until the time of analysis. To analyze the oxidation level of the samples, analysis of acidity, peroxide index and conjugated dienes were performed by the American Oil Chemists' Society standard analysis (AOCS, 2009). All analysis, except for the conjugated dienes, performed on the treatments were done in duplicate.

\section{Content of free fat acids}

This method determined the free fatty acids present in the sample, expressed as oleic acid (\%). It was conducted according to the official AOCS method Ca 5a-40 (2009).

\section{Peroxide index}

The peroxide index is the amount of active oxygen, calculated in milliequivalents, contained in one kilogram of oil, measured from the iodine released from potassium iodide by the peroxides present in the oil. This index was determined according to the AOCS standard Cd 8-53 (2009). 


\section{Conjugated dienes}

This method determined conjugated dienes present in the fatty matter, expressed as a percentage of conjugated dienoic acids. The readings were carried out in triplicate at the wavelength of $233 \mathrm{~nm}$, spectrophotometer model U-1800 by Hitachi. The determination of conjugated dienes was carried out according to the official method AOCS Ti 1a-64 (2009).

\section{Statistical analysis}

To perform the statistical analysis, the procedures for antioxidant activity were performed in triplicate and the analysis to determine the level of lard oxidation, except for the conjugated dienes, were performed in duplicate and submitted to the variance test (ANOVA) and the $5 \%$ Tukey test in the software Statistica $® 10$.

\section{RESULTS AND DISCUSSION}

\section{Antioxidant activity, total phenolic compounds and total flavonoids of the rosemary extract and rosemary essential oil}

The results for all analysis for the antioxidant activity of rosemary extract and rosemary essential oil (Table 2), all values are followed by the standard deviation. According to the analysis of the DPPH method, the rosemary extract had better results than the rosemary essential oil, since the lower the concentration to inhibit $50 \%$ of the radical $\mathrm{DPPH}^{\circ}$ the better the antioxidant potential. Morais et al. (2009) found values of 1740.00 and $1736.00 \mu \mathrm{g} \mathrm{mL}^{-1}$ for methanolic extract of mint and lemongrass (Cymbopogon citratus). The activity potential for rosemary extract and rosemary essential oil were 0.03 and 0.02 respectively, therefore classified as weak antioxidants, however, these values could increase with a higher concentration $\left(>100 \mathrm{mg} \mathrm{kg}^{-1}\right)$ of the extract and the essential oil. Regarding the analysis of the $\mathrm{ABTS}^{\circ+}$ method, the antioxidant activity for rosemary extract had a value approximately three times higher than the essential oil, demonstrating a better protection capacity for the extract.

Primary antioxidants, such as rosemary extract and rosemary essential oil, act to capture free radicals formed during the early stages of auto-oxidation, preventing the occurrence of subsequent steps. The two methods, $\mathrm{DPPH}^{\circ}$ and $\mathrm{ABTS}^{+*}$, correlate in methodology and, as demonstrated, their results as well, since they use electron donation as a principle. Therefore, the values obtained were satisfactory.

Table 2. Antioxidant activity, total phenolic compounds (TPC) and total flavonoids (TF) results

\begin{tabular}{|c|c|c|c|c|}
\hline Sample & $\begin{array}{l}\text { DPPH' }\left(E^{-150}\right) \\
\left(\mu \mathrm{mL}^{-1}\right)\end{array}$ & $\begin{array}{c}\text { ABTS }^{\circ+} \\
\left(\mu \mathrm{mol} \mathrm{ET} \mathrm{mL}^{-1}\right)\end{array}$ & $\begin{array}{c}\text { TPC } \\
\left(\mathrm{mg} \mathrm{EGA} \mathrm{L}^{-1}\right)\end{array}$ & $\begin{array}{c}\mathrm{TF} \\
\left(\mu \mathrm{gER} \mathrm{mL}^{-1}\right)\end{array}$ \\
\hline R. extract & $1519.61^{b} \pm 0.29$ & $917.87^{a} \pm 0.02$ & $99.55^{a} \pm 6.38$ & $29.79^{a} \pm 0.53$ \\
\hline R. essential oil & $1851.51^{\mathrm{a}} \pm 0.36$ & $321.71^{b} \pm 0.01$ & $80.88^{a} \pm 14.48$ & $31.42^{a} \pm 0.74$ \\
\hline
\end{tabular}

The analysis of total phenolic compounds for rosemary extract and rosemary essential oil resulted in different values, but when analyzed statistically they do not differ 
from each other. Similar values were found by Silva, Cury and Salomão (2016) of 101.10 mg EAG L ${ }^{-1}$ for the alcoholic bay leaf extract and by Angelo and Jorge (2008) of $92.00 \mathrm{mg}$ $E A G L^{-1}$ for the coriander extract obtained by aqueous extraction and centrifugation.

As for total flavonoid analysis, the results again showed no statistical difference from each other. Povh, Santos and Silva (2012) found values of 23,33 and 33,33 $\mu \mathrm{g}$ ER $\mathrm{mL}^{-1}$ for Hyptis microphylla and Hyptis lantanifolia extracts obtained by mixing with solvent (acetone $70 \% \mathrm{v} / \mathrm{v}$ ), followed by filtration and centrifugation, both are aromatic plants that are found in the Brazilian cerrado.

\section{Lard thermoxidized analysis}

It is possible to observe the results of fatty acid content, peroxides index and conjugated dienes (Table 3 ). When observing the resulting data, the free fatty acids content in all samples has increased throughout the thermoxidation. The treatment with TBHQ ( $L+T B H Q)$ had better results from the period of 10 to 20 hours, however the essential oil treatment showed statistically the same result as the synthetic antioxidant for the period of 20 hours. All these values are in agreement with the maximum of $3 \%$ allowed by the Brazilian legislation for common lard and refined common lard (Brazil, 2017).

Table 3. Averages of free fatty acids, peroxides and conjugated dienes for lard during thermoxidation

\begin{tabular}{|c|c|c|c|c|c|}
\hline \multirow[t]{2}{*}{ Treatments } & \multicolumn{5}{|c|}{ Thermoxidation periods (hours) } \\
\hline & 0 & 5 & 10 & 15 & 20 \\
\hline \multicolumn{6}{|c|}{ Free fat acids (\%) } \\
\hline $\mathrm{L}$ & $0.81^{\mathrm{aA}} \pm 0.03$ & $1.00^{\mathrm{CA}} \pm 0.06$ & $1.18^{\mathrm{DA}} \pm 0.06$ & $1.16^{\mathrm{bA}} \pm 0.01$ & $1.44^{\mathrm{aA}} \pm 0.01$ \\
\hline $\mathrm{L}+\mathrm{TBHQ}$ & $0.78^{\mathrm{db}} \pm 0.01$ & $0.94^{\mathrm{CB}} \pm 0.01$ & $0.94^{\mathrm{CD}} \pm 0.02$ & $1.03^{b C} \pm 0.03$ & $1.23^{\mathrm{ab}} \pm 0.06$ \\
\hline$L+R E$ & $0.73^{\mathrm{eC}} \pm 0.01$ & $0.86^{\mathrm{dC}} \pm 0.03$ & $1.00^{\mathrm{CB}} \pm 0.01$ & $1.17^{\mathrm{DA}} \pm 0.01$ & $1.40^{\mathrm{aA}} \pm 0.01$ \\
\hline $\mathrm{L}+\mathrm{REO}$ & $0.67^{\mathrm{ev}} \pm 0.01$ & $0.84^{\mathrm{dC}} \pm 0.05$ & $0.96^{c C} \pm 0.02$ & $1.14^{\mathrm{bb}} \pm 0.04$ & $1.23^{\mathrm{ab}} \pm 0.01$ \\
\hline \multicolumn{6}{|c|}{ Peroxide index $\left(\mathrm{meq} \mathrm{kg}^{-1}\right)$} \\
\hline $\mathrm{L}$ & $4.17^{\mathrm{dA}} \pm 0.29$ & $18.77^{\mathrm{CB}} \pm 0.47$ & $34.72^{\mathrm{aA}} \pm 0.24$ & $31.33^{\mathrm{bA}} \pm 0.47$ & $30.81^{\mathrm{bB}} \pm 0.33$ \\
\hline$L+T B H Q$ & $4.47^{\mathrm{eA}} \pm 0.13$ & $18.75^{\mathrm{db}} \pm 0.32$ & $22.48^{\mathrm{CL}} \pm 0.36$ & $27.39^{\mathrm{bB}} \pm 0.02$ & $30.71^{\mathrm{ab}} \pm 0.26$ \\
\hline$L+R E$ & $3.67^{\mathrm{eA}} \pm 0.18$ & $20.45^{\mathrm{dA}} \pm 0.41$ & $24.16^{\mathrm{CC}} \pm 0.61$ & $28.68^{\mathrm{bB}} \pm 0.16$ & $34.60^{\mathrm{aA}} \pm 0.24$ \\
\hline$L+R E O$ & $4.10^{\mathrm{dA}} \pm 0.13$ & $21.88^{\mathrm{CA}} \pm 0.40$ & $26.31^{\mathrm{bb}} \pm 0.38$ & $30.73^{\mathrm{aA}} \pm 0.27$ & $31.76^{\mathrm{ab}} \pm 0.31$ \\
\hline \multicolumn{6}{|c|}{ Conjugated dienes (\%) } \\
\hline $\mathrm{L}$ & $0.11^{\mathrm{bs}}$ & --- & --- & --- & $1.18^{\mathrm{aA}}$ \\
\hline$L+T B H Q$ & $0.13^{\mathrm{bB}}$ & --- & --- & --- & $0.97^{\text {ав }}$ \\
\hline$L+R E$ & $0.16^{\mathrm{DA}}$ & --- & --- & --- & $1.00^{\text {ав }}$ \\
\hline$L+R E O$ & $0.16^{\mathrm{DA}}$ & --- & --- & --- & $0.98^{\text {ав }}$ \\
\hline
\end{tabular}

In the lines, which represent different times for the same treatment, averages followed by the same lowercase letter do not differ by the Tukey's test $(p>0.05)$.

In the columns, which represent different treatment for the same time, averages followed by the same capital letter do not differ by the Tukey's test $(p>0.05)$.

It is possible to observe that for the peroxide index, there was a decline from 10 hours of heating for the control sample (L). Therefore, it is possible to say that the control showed signs of advanced levels of oxidation, because in the termination phase of the autoxidation there is the decomposition of the peroxides that were formed in the propagation phase, this characteristic was not observed in the other treatments. Regarding the other treatments, the lard added of TBHQ $(\mathrm{L}+\mathrm{TBHQ})$ had the lowest values throughout the process but ending with similar results with the rosemary essential oil 
treatment $(L+R E O)$. Comparing the lard added of rosemary extract $(L+E O)$ and the lard added of rosemary essential oil ( $L+R E O)$, the extract had good results during the periods of 5,10 and 15 hours, but in the 20 hours the essential oil treatment ( $L+R E O)$ had a better result. The Brazilian legislation does not stablish limits of peroxide index for lard, however these limits are stablished for vegetable oils such as refined oils, unrefined oils and virgin olive oil, for these vegetable oils the limits are 10, 15 and 20 meq $\mathrm{kg}^{-1}$, respectively (Brazil, 2005)

According to the values found for conjugated dienes (Table 3 ), it is possible to observe that after a period of 20 hours the control had a significant increase of conjugated dienes comparing with the samples with antioxidants. The treatments with natural antioxidants $(L+R E O$ and $L+E O)$ showed statistically the same value as the synthetic one $(\mathrm{L}+\mathrm{TBHQ})$. Both peroxide index and conjugated dienes are not analysis stablished by the Brazilian legislation for lard and vegetable oil quality.

The results showed that rosemary essential oil had results as good as the obtained by the synthetic antioxidant TBHQ at the same concentration $\left(100 \mathrm{mg} \mathrm{kg}^{-1}\right)$. The rosemary extract showed also good results when compared with the control, in addition, the natural antioxidants presented here can be used in higher concentrations than the synthetic ones, so they may get even better results.

\section{CONCLUSIONS}

Rosemary extract obtained better results for the antioxidant capacity analysis when compared to rosemary oil. Despite this difference, both oil and extract are potential natural antioxidants.

In a general setting, rosemary essential oil obtained results as good as those of the antioxidant TBHQ during the thermoxidation treatments, demonstrating that antioxidants from natural sources can replace synthetic ones without difference. More studies are needed with the use of different concentrations, even when used in synergy with other synthetic antioxidants, to know the real antioxidant power that rosemary in an industrial scale can offer.

\section{REFERENCES}

ALADEDUNYE, F.; MATTHÄUS, B. Phenolic extracts from Sorbus aucuparia (L.) and Malus baccata (L.) barriers: antioxidant activity and performance in rapeseed oil during frying storage. Food Chemistry, v. 159, p. 273-281, 2014.

ALMEIDA-DORIA, R. F.; REGITANO-D'ARCE, M. A. B. Antioxidant Activity of Rosemary and Orégano Ethanol Extracts in Soybean Oil Under Thermal Oxidation. Ciência e Tecnologia de Alimentos, v. 20, n. 2, 2000.

ANGELO, P. M.; JORGE, N. Efeito oxidante do extrato de coentro e palmitato de ascorbila na estabilidade oxidativa do óleo de girassol. Revista do Instituto Adolfo Lutz, v. 67, n. 1, p. 34-38, 2008.

AOCS. AMERICAN OIL CHEMISTS SOCIETY. Official methods and recommended practices of the American Oil Chemists' Society. 6. ed. Chicago: AOCS, 2009. 
BOTTERWECK, A. A. M. et al. Intake of Butylated Hydroxyanisole and Butylated Hydroxytoluene and Stomach Cancer Risk: Results from Analyses in the Netherlands Cohort Study. Food and Chemical Toxicology, p. 599-605, 1999.

BRAND-WILLIAMS, W.; CUVELIER, M. E.; BERSET, C. Use of a free radical method to evaluate antioxidant activity. LWT - Food Science and Technology,p. 25-30, 281995.

BRASIL. Decreto $n^{\circ}$ 50040, de 24 de janeiro de 1961. Dispõe sobre Normas Técnicas Especiais Reguladoras do Emprego de Aditivos Químicos a Alimentos. Disponivel em: http://portal.anvisa.gov.br/documents/33916/391619/DECRETO+N\%C2\%BA+50.040\%2C +DE+24+DE+JANEIRO+DE+1961.pdf/bb735327-8381-4966-b9d9-627e158d6bcf. Acesso em: 30 nov. 2018.

BRASIL. Resolução RDC n 270 de 22 de setembro de 2005. Regulamento técnico para óleos vegetais e creme vegetal. Disponivel em: http://www.oliva.org.br/wp-360 content/uploads/2016/11/resolucao-rdc-n270-22-09-2005.pdf. Acesso em: 10 de dez. de 3612018.

BRASIL. Decreto n 9.013 de 29 de março de 2017. Regulamento da Inspeção Industrial e Sanitária de Produtos de Origem Animal - RIISPOA. Disponivel em:

http://www.agais.com/normas/riispoa/riispoa_titulo7a.pdf. Acesso em: 1 de nov. de 2018.

CASAROTTI, S. N.; JORGE, N. Antioxidant activity of rosemary extract in soybean oil under thermoxidation. Journal of Food Processing and Preservation, v. 38, n. 1, p. 136-145, 2014.

FANG, X.; WADA, S. Enhancing the antioxidant effect of a-tocopherol with rosemary in inhibiting catalyzed oxidation caused by $\mathrm{Fe} 2+$ and hemoprotein. Food Research International, v. 26, n. 1, p. 405-411, 1993.

GORDON, M. H.; KOURIMSKÁ, L. Effect of antioxidants on losses of tocopherols during deep-fat frying. Food Chemistry, v. 52, n. 1, p. 175-177, 1995.

KUSKOSKI, E. M. et al. Aplicacíon de diversos métodos químicos para determinar actividad antioxidante en pulpa de frutos. Ciência e Tecnologia de Alimentos, v. 25, n. 4, p. 726-732, 2005.

MORAIS, S. M. D. et al. Ação antioxidante de chás e condimentos de grande consumo no Brasil. Revista Brasileira de Farmacognosia, p. 315-320, 2009.

OIL World Annual. Oil World, 2018. Disponível em: <https://www.oilworld.biz/t/publications/annual>. Acesso em: 17 de dez. de 2018.

POVH, J. A.; SANTOS, F. B.; SILVA, K. R. Teor de fenóis totais e flavonoides em quatro espécies do gênero Hyptis Jacq. ocorrentes no cerrado stricto sensu. Brazilian Geographical Journal: Geosciences and Humanities research medium, v. 3, n. 2, p. 520528, 2012. 
RE, R. et al. Antioxidant activity applying an improved ABTS radical cation decolorization assay. Free Radical Biology and Medicine, v. 26, n. 9-10, p. 1231-1237, 1999.

RESENDE, E. L. ABCS 60 Anos: A Suinocultura Além da Porteira. 1ª ed. Brasília: Duo Design Comunicação, 2014.

SCHERER, R.; GODOY, H. T. Antioxidant activity index (AAI) by the 2,2-diphenyl-1picrylhydrazyl method. Food Chemistry, v. 112, n.3, p. 654-658, 2009.

SILVA, A. C.; CURY, Y. S.; SALOMÃO, R. S. Utilização de extrato de louro (Laurus nobilis) como antioxidante natural em óleo de soja termoxidado. In: V Simpósio de Engenharia e Ciência de Alimentos, 5, 2016, São José do Rio Preto.

SINGLETON, V. L.; ROSSI, J. A. Colorimetry of total phenolics with phosphotungstic. American Journal of Enology and Viticulture, v. 16, n. 3, p. 144-158, 1965.

SOBRINHO, T. J. D. S. P. et al. Validação de metodologia espectrofotométrica para quantificação dos flavonóides de Bauhinia cheilantha (Bongard) Steudel. Revista Brasileira de Ciências Farmacêuticas, v. 44, n. 4, p. 683-689, 2008.

VENKATESH, R.; SOOD, D.; SHIVKUMAR, S. A Review of the Physiological Implications of Antioxidants in Food. 2011. Dissertação (Graduação em Ciência) - Worcester Polytechinic Institute, Worcester.

WU, J. W. et al. Elucidation of the chemical structures of natural antioxidants isolated from rosemary. Journal of the American Oil Chemists' Society, v. 59, n. 1, p. 339-345, ago. 1982.

Recebido em: 07/02/2019

Aprovado em: 01/05/2019 